\title{
Evaluation of Investment Management and Business Performance in Wood Processing Industry in Slovakia
}

\section{Vrednovanje upravljanja investicijama i poslovanjem u drvoprerađivačkoj industriji u Slovačkoj}

\author{
Preliminary paper • Prethodno priopćenje \\ Received-prispjelo: 21. 11. 2014. \\ Accepted-prihvaćeno: 20. 5. 2015. \\ UDK: $630 * 79 ; 658.5$ \\ doi: $10.5552 /$ drind.2015.1439
}

\begin{abstract}
The aim of this paper was to analyze certain parameters of investment measurement and management of companies in Slovakia, especially in wood processing industry compared with other industrial sectors. Statistical analysis was made of relationships between investment trends and performance given by the indicator Return on Equity. The goal was to identify differences in investment management of analyzed industries and consequently define relevant determinants as critical areas with the impact on performance of wood processing companies. In the results of research, special interest is focused on crucial investments with the emphasis on the preparation of investment projects.
\end{abstract}

Key words: enterprise investment, investment trends, business performance, wood processing industry, Slovakia

SAŽETAK • Provedena istraživanja bila su usmjerena na parametre mjerenja investicija i upravljanja poduzećima u Slovačkoj, posebice u drvoprerađivačkim poduzećima u usporedbi s drugim industrijskim sektorima. Statistički je analizirana međusobna ovisnost investicijskih trendova i rezultata poslovanja dobivenih putem indeksa točke povrata. Cilj rada bio je odrediti razlike u upravljanju investicijama između promatranih industrijskih grana $i$ slijedom toga odrediti relevantna obilježja kao kritična područja koja utječu na poslovne rezultate drvoprerađivačkih poduzeća. U rezultatima istraživanja posebna je pozornost pridana ključnim investicijama, s naglaskom na pripremi investicijskih projekata.

Ključne riječi: investicije u poduzeću, investicijski trendovi, poslovni rezultati, drvoprerađivačka industrija, Slovačka

\footnotetext{
${ }^{1}$ Authors are assistant and associate professor at Technical University in Zvolen, Faculty of Wood Sciences and Technology, Department of Enterprise Management, Zvolen, Slovak Republic. ${ }^{2}$ Author is professor at University of Zagreb, Faculty of Forestry, Zagreb, Croatia. Autori su asistentica i izvanredni profesor Tehničkog sveučilišta u Zvolenu, Fakultet za znanost o drvu i tehnologiju, Zavod za poslovno upravljanje, Zvolen, Slovačka. ${ }^{2}$ Autor je profesor Sveučilišta u Zagrebu, Šumarski fakultet, Zagreb, Hrvatska.
} 


\section{INTRODUCTION}

\section{UVOD}

Also due to the significant factors in the context of global economic crisis, the wood processing industry (WPI) has to face the fall in demand for timber and timber products not only in Slovakia. Consequently, many small businesses were lost. If demand is not stimulated in the short term, the performance of WPI as a whole will clearly decrease, which will of course adversely affect the WPI share in the GDP of Slovakia in future (min. 5 years), as well as balanced regional development (availability of raw materials), with negative impact on social stability of individual regions in Slovakia (Merková and Drábek, 2011).

Slovakia currently exports large quantities of raw wood, much of which is renewable raw material, this being a significant comparative advantage for the WPI of SR. The wood stock in Slovak forests has been continuously increasing. Wood harvesting in Slovakia is also growing. The maximum annual volume of wood harvest was reached in 2005 as the result of unusually strong wind storm in 2004. The increase of harvest increases also the economic potential of Slovak forests (Moravčík, 2007, SARIO). In case of foreign capital invested in new technologies for processing of domestic raw materials, potential effects from foreign direct investment would especially result in a higher value added in the WPI, and in the growth of the WPI share in the GDP of Slovakia.

Woodworking and furniture industry is developed in Slovakia and it is more than necessary. Forests and sophistically used wood constantly produced by forests are the basis for the development of WPI, which may be a strategic issue for the Slovak economy. Increased consumption of wood in the Slovak Republic and focus on domestic production can best help companies to find solutions in a currently difficult situation.

Recent development in most enterprises suggests that the effects of the global economic crisis have a significant impact on the performance of enterprises, with direct impact on the level of economy as well as the level of investment. The development of each sector or company requires appropriate investment. Without investment, economic objectives of the business cannot fully be met (Merková et al., 2011).

Investment decision-making is one of fundamental parts in performance management of companies (Ojurović et al., 2013). However, to meet the strategic goals, a company needs to apply successful methods for management and measurement of business performance (Merková and Drábek, 2010; Merková and Drábek, 2013). The allocation of available financial resources to fixed assets or investments in modernization of production technologies are possible ways when a company can ensure its prosperity. Implementation of process principles into management brings a lot of changes with positive effects as higher competitiveness, productivity and performance (Sujová et al., 2014).

"A lively discussion on the relevance of the application of selected indicators for measuring the busi- nesses performance" is nowadays conducted between representatives of the theory, consulting firms and business. Different opinions and views are based on two facts as follows:

- normal, so far commonly used performance indicators are related to the past and it is highly questionable whether they sufficiently reflect the company's future competitiveness,

- used indicators do not sufficiently reflect the quality of customer relationships.

It can be concluded that the economic experience quite often results in financial management based on the accounting profit and common indicators such as profitability or activity ratios. These indicators are presently considered as insufficient, which is also one of the reasons for the significantly poor competitiveness of enterprises. Traditional methods of measuring business performance (for example in Knápková and Pavelková, 2010 or Kislingerová, 1999) are based primarily on maximizing profits (which is also in line with the objectives of business activity). Absolute and relative indicators are used for measuring the performance (Kislingerová, 2010). However, in recent years objections to the traditional performance measurement indicators, such as profitability, can be seen.

In evaluating an investment, attention is focused on suitability, efficiency and feasibility of a specific project. Moreover, the impact of the project on the total effectiveness, prosperity and financial stability of the company is evaluated (Polách et al. 2012; Rajnoha et al., 2014 and others). Discounted cash-flow methods for investment valuation take time factor into consideration. In economic life, time factor makes things more serious, it enables the change of money evaluation. Based on a wrong change, a wrong decision can be made, which would have significant influence on project effectiveness and enterprise stability (Drábek and Jelačić, 2007). Discounted cash-flow methods underlie two basic rules of financing (see more in Brealey and Myers, 1999 or Brealey and Myers, 2003) considering time changes of money values. While discounted cash flow valuation is only one of the three ways of approaching valuation, it is the foundation on which all other valuation approaches are built (Damodaran, 2012).

Business performance was analyzed by our research team recently with the objective to determine the extent of the use of traditional and modern indicators, methods and models of performance management on a sample of randomly selected companies in various industries of Slovakia. Rajnoha et al. (2013) published the research results and demonstrated the impact of selected factors in the performance of surveyed companies.

There is the possibility to consider the prices. However, investors will not certainly decide for the lowest current price - such as low production costs and cheap labor or low tax cost - but primarily on the lowest cost throughout the life cycle of the investment (Merková et al., 2012). Apart from the quality of infrastructure, size of the domestic market or access to regional and international markets, foreign investors particularly take into account the factors such as energy 
costs, availability of suppliers and customers, sufficient qualified and skilled workforce, predictability of economic development, stability of legislative conditions, security of companies and others.

The aim of this paper is to analyze the investment measurement and management of companies in Slovakia by investigating the investment trends and decisions such as routing, types, direction and objectives of investment activity, investment development and preparation of investment projects.

The research objective was to analyze certain parameters of investment measurement and management, and consequently statistically analyze the relationships and differences between investment trends and performance given by the indicator Return on Equity. The goal was to find out relevant determinants as critical areas with the impact on performance of wood processing companies. The results were analyzed based of the questionnaire.

Selected results of the research presented in this paper analyze as follows:

- Obtained business performance in research samples,

- Share of development investment in companies,

- Investing directions and crucial investments,

- Emphasis on preparation of investment projects.

This paper gives a comparison of the current investment management in the wood processing industry of the Slovak Republic (WPI SR) and other industrial sectors.

\section{METHODOLOGY OF RESEARCH} 2. METODOLOGIJA ISTRAŽIVANJA

Methodologically, an on-line questionnaire was developed (more in Questionnaire Survey) through internet application to collect data from companies in Slovakia. Complete anonymity of participating firms was granted. The size of research sample was 164 counts.

The research was primarily focused on wood processing companies. Statistical classification of Economic Activities (NACE Rev. 2) in the Statistical Office of the Slovak Republic defines as follows:
- Manufacture of wood (Wood industry - WI)

- Manufacture of pulp and paper products (Pulp and paper industry - PPI)

- Manufacture of furniture (Furniture industry - FI).

The aim was also to analyze specific sectors included in wood processing, e.g. the pulp and paper industry ( 2 companies), the furniture industry (11 companies) would cause low relevance of the results for the two-dimensional statistics, because these sectors were individually assessed only by means of univariate descriptive statistics. For two-dimensional statistics for qualitative (nominal) variables, the related sectors were put together. In this case, the sample included all sectors of the wood processing industry (WPI) covering 34 companies. Basic information about research samples used in this part of research is presented in Tab. 1.

Companies were initially analyzed according to the distribution of the achieved performance of 6 particular groups (group 0-5, group 0 - the worst performance with negative ROE, group 5 - the best performance with ROE over $10 \%$ ).

Mathematical and statistical methods were used in the research of interdependencies and impacts of individual factors on achieved performance of companies.

One-dimensional inductive statistics:

In the research, selected descriptive statistics was analyzed for one variable - absolute and relative frequencies, cumulative frequency and cumulative relative frequency, mean, median and mode. The following statistical methods were used: frequency tables showing the frequency by categories, histograms, pie charts, bar and cumulative bar charts, time series and trends.

Two-dimensional inductive statistics between categorical variables

The research consisted of qualitative - nominal variables, their relationship cannot adequately describe the correlation analysis, so the association between variables was examined with contingency (first used by Pearson, 1904).

Cumulative bar graph represents the best way to present graphically the relationship between a pair of categorical variables. In fact, it is a graphical representation of row or column percentages in contingency table (Rimarčík, 2007).

Table 1 Research samples

Tablica 1. Poligoni istraživanja

\begin{tabular}{|l|l|}
\hline $\begin{array}{l}\text { Research sample / Industry } \\
\text { Poligon istraživanja / Industrijske grane }\end{array}$ & $\begin{array}{l}\text { Sample size } \\
\text { Veličina uzorka }\end{array}$ \\
\hline $\begin{array}{l}\text { Sample of all tested companies } \\
\text { Veličina uzorka svih ispitanih poduzeća }\end{array}$ & $\begin{array}{l}164 \text { companies } \\
164 \text { poduzeća }\end{array}$ \\
\hline $\begin{array}{l}\text { Sample of WPI companies - Industries included in WPI: WI, FI, PPI } \\
\text { Veličina uzorka drvoprerađivačkih poduzeća uključujući primarne proizvode, finalne proizvode te } \\
\text { proizvodnju celuloze i papira }\end{array}$ & $\begin{array}{l}34 \text { companies } \\
34 \text { poduzeća }\end{array}$ \\
\hline $\begin{array}{l}\text { Sample of automotive companies } \\
\text { Veličina uzorka poduzeća za proizvodnju automobila }\end{array}$ & $\begin{array}{l}16 \text { companies } \\
16 \text { poduzeća }\end{array}$ \\
\hline $\begin{array}{l}\text { Sample of engineering companies } \\
\text { Veličina uzorka poduzeća u metaloprerađivačkoj industriji }\end{array}$ & $\begin{array}{l}30 \text { companies } \\
30 \text { poduzeća }\end{array}$ \\
\hline $\begin{array}{l}\text { Sample of other companies (all other industries except WPI, automotive and engineering) } \\
\text { Veličina uzorka ostalih poduzeća (sve ostale industrijske grane bez drvoprerađivačke, automobilske i } \\
\text { metaloprerađivačke) }\end{array}$ & $\begin{array}{l}84 \text { companies } \\
84 \text { poduzeća }\end{array}$ \\
\hline
\end{tabular}


Chi-squared test was applied. It is commonly used for testing the independence between two categorical variables. Results of chi-squared tests describe selected statistics: Pearson's chi-square and significance $p$-value , ,p“, Maximum-Likelihood chi-square and p-value, Pearson's Contingency Coefficient $(C C)$, Adjusted Contingency Coefficient (Adj. CC) and degrees of freedom $(d f)$.

Pearson's Chi-square:

$\chi^{2}=\sum_{i=1}^{k}\left[\left(f_{o_{i}}-f_{e_{i}}\right)^{2} / f_{e_{i}}\right]$

while $\quad \sum\left(f_{o}-f_{e}\right)=0$

Pearson's contingency coefficient $C C$ :

$C C=\sqrt{\left(\chi^{2} / \chi^{2}+N\right)}$

Maximum contingency coefficient $C C_{\max }$ :

$C C_{\max }=\sqrt{(q-1) / q}$

Adjusted contingency coefficient

Adj. $C C=C C / C C_{\max }$; while $C C \leq C C_{\max }$

Where:

$f_{o_{i}}$ - observed frequency in a field of the table,

$f_{e_{i}}$ - expected (theoretical) frequency in a field of the table,

$k$ - number of cells in the table

$N$ - sample size

$q$ - number of rows or columns (in square tables).

MS Office Excel and Statistic software from Stat

Soft, Inc. was used for statistical analysis, and numeric and graphical presentation of the research results.

\section{RESEARCH RESULTS}

3. REZULTATI ISTRAŽIVANJA

\subsection{Development investment}

\subsection{Razvojne investicije}

Development investments (expansion, starting of new production, etc.) were analyzed in contrast with recovery investments. Development investments were divided into 5 categories. It can be seen from the de-

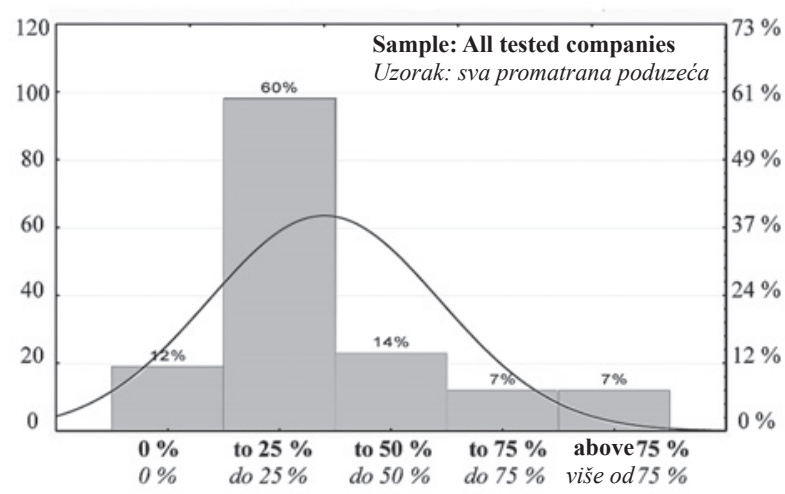

Figure 1 Histograms: Share of development investment Slika1. Histogrami: Udio razvojnih investicija scriptive statistical results (Figure 1) that most enterprises in both presented samples implement development investment in the share of $25 \%$ of the total investment in company (60\% of respondents in all enterprises and $62 \%$ of WPI businesses).

Low abundance $(6 \%)$ speaks in favor of WPI in the category with zero share of expansion investment, while a relatively high number of enterprises $(21 \%)$ was recorded with development investments in the range of $25-50 \%$. In all enterprises, more negative representation (12\%) of the category without development investments was evaluated. On the other hand, the highest category - massive expansion investments with a $75 \%$ share was recorded in $7.32 \%$ of all tested enterprises, but only in $2.94 \%$ of WPI businesses. The observed frequencies and relative frequencies in different six performance groups are presented in Tab. 2 and 3 .

The observed frequencies presented in both samples show that firms realizing a high share of expansion investments above $75 \%$ reach lower performance (mostly in the performance group 0 with negative ROE indicator). At currently implemented investments, return and higher business performance are expected later in the long term. By applying statistical methods, no significant relationship has been shown between the share of development investment and performance of businesses in any research sample.

The average performance was also analyzed in each category (Tab. 4). The results revealed growing performance based on a higher percentage of expansion investments between categories of $25 \%, 50 \%$ and $75 \%$ of all enterprises. It can, therefore, be stated that development investments proportionally influence the growth of business performance, but only to a certain extent. As companies invest in the development more than $75 \%$, they are inefficient in the initial period. The data averages, however, also showed that firms without development investments achieve the performance level of enterprises with 25 and $50 \%$ share of development investments. This performance is probably only temporary and companies without investing in development in the coming years will be less powerful. Testing the differences in the averages of categories showed no statistically significant relationship between the investments in the development and performance of businesses.

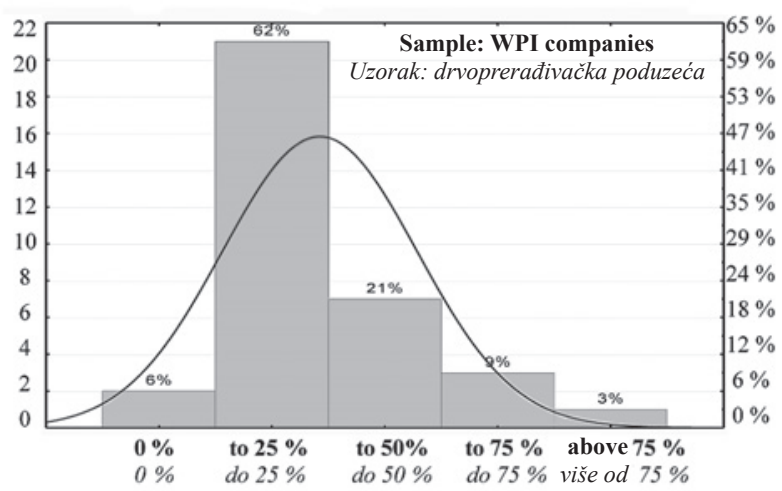


Table 2 Observed frequencies: Share of development investment - all tested companies

Tablica 2. Učestalost: Udjeli razvojnih investicija u svim promatranim poduzećima

\begin{tabular}{|c|c|c|c|c|c|c|c|}
\hline $\begin{array}{l}\text { Share of develop- } \\
\text { ment investment } \\
\text { Udio razvojnih } \\
\text { investicija }\end{array}$ & $\begin{array}{c}\text { Group 0 } \\
\mathbf{R O E}<\mathbf{0} \\
\text { Skupina 0, } \\
\text { točka povrata } \\
<0\end{array}$ & $\begin{array}{c}\text { Group 1 } \\
\text { ROE: 0-2 \% } \\
\text { Skupina 1., } \\
\text { točka povrata } \\
\text { 0-2\% }\end{array}$ & \begin{tabular}{|c|} 
Group 2 \\
ROE: 2-4 \% \\
Skupina $2 .$, \\
točka povrata \\
$2-4 \%$
\end{tabular} & $\begin{array}{c}\text { Group } 3 \\
\text { ROE: 4-7 \% } \\
\text { Skupina 3., } \\
\text { točka povrata } \\
\text { 4-7\% }\end{array}$ & $\begin{array}{c}\text { Group } 4 \\
\text { ROE: } 7-10 \% \\
\text { Skupina } 4 ., \\
\text { točka povrata } \\
7-10 \%\end{array}$ & $\begin{array}{c}\text { Group 5 } \\
\text { ROE }>\mathbf{1 0} \% \\
\text { Skupina 5., } \\
\text { točka povrata } \\
>10 \%\end{array}$ & $\begin{array}{c}\text { Row } \\
\text { Totals } \\
\text { Ukupno }\end{array}$ \\
\hline $0 \%$ & 5 & 3 & \begin{tabular}{|l|}
2 \\
\end{tabular} & \begin{tabular}{|l|}
5 \\
\end{tabular} & 2 & 2 & 19 \\
\hline $\begin{array}{l}\text { Share in category } \\
\text { Udio po kategoriji }\end{array}$ & $26.32 \%$ & $15.79 \%$ & $10.53 \%$ & $26.32 \%$ & $10.53 \%$ & $10.53 \%$ & $100 \%$ \\
\hline $\begin{array}{l}\text { Share in total } \\
\text { Udio u ukupnosti }\end{array}$ & $3.05 \%$ & $1.83 \%$ & $1.22 \%$ & $3.05 \%$ & $1.22 \%$ & $1.22 \%$ & $11.59 \%$ \\
\hline up to $25 \% /$ do $25 \%$ & 11 & 33 & 25 & 12 & 7 & 10 & 98 \\
\hline $\begin{array}{l}\text { Share in category } \\
\text { Udio po kategoriji }\end{array}$ & $11.22 \%$ & $33.67 \%$ & $25.51 \%$ & $12.24 \%$ & $7.14 \%$ & $10.20 \%$ & $100 \%$ \\
\hline $\begin{array}{l}\text { Share in total } \\
\text { Udio u ukupnosti }\end{array}$ & $6.71 \%$ & $20.12 \%$ & $15.24 \%$ & $7.32 \%$ & $4.27 \%$ & $6.10 \%$ & $59.76 \%$ \\
\hline up to $50 \% /$ do $50 \%$ & 2 & 7 & 4 & 6 & 2 & 2 & 23 \\
\hline $\begin{array}{l}\text { Share in category } \\
\text { Udio po kategoriji }\end{array}$ & $8.70 \%$ & $30.43 \%$ & $17.39 \%$ & $26.09 \%$ & $8.70 \%$ & $8.70 \%$ & $100 \%$ \\
\hline $\begin{array}{l}\text { Share in total } \\
\text { Udio u ukupnosti }\end{array}$ & $1.22 \%$ & $4.27 \%$ & $2.44 \%$ & $3.66 \%$ & $1.22 \%$ & $1.22 \%$ & $14.02 \%$ \\
\hline up to $75 \% /$ do $75 \%$ & 1 & 1 & 3 & 3 & 1 & 3 & 12 \\
\hline $\begin{array}{l}\text { Share in category } \\
\text { Udio po kategoriji }\end{array}$ & $8.33 \%$ & $8.33 \%$ & $25.00 \%$ & $25.00 \%$ & $8.33 \%$ & $25.00 \%$ & $100 \%$ \\
\hline $\begin{array}{l}\text { Share in total } \\
\text { Udio u ukupnosti }\end{array}$ & $0.61 \%$ & $0.61 \%$ & $1.83 \%$ & $1.83 \%$ & $0.61 \%$ & $1.83 \%$ & $7.32 \%$ \\
\hline $\begin{array}{l}\text { above } 75 \% \\
\text { više od } 75 \%\end{array}$ & 6 & 3 & 1 & 0 & 0 & 2 & 12 \\
\hline $\begin{array}{l}\text { Share in category } \\
\text { Udio po kategoriji }\end{array}$ & $50.00 \%$ & $25.00 \%$ & $8.33 \%$ & $0.00 \%$ & $0.00 \%$ & $16.67 \%$ & $100 \%$ \\
\hline $\begin{array}{l}\text { Share in total } \\
\text { Udio u ukupnosti }\end{array}$ & $3.66 \%$ & $1.83 \%$ & $0.61 \%$ & $0.00 \%$ & $0.00 \%$ & $1.22 \%$ & $7.32 \%$ \\
\hline $\begin{array}{l}\text { Counts total } \\
\text { Ukupan broj }\end{array}$ & 25 & 47 & 35 & 26 & 12 & 19 & 164 \\
\hline $\begin{array}{l}\text { Share total } \\
\text { Ukupan udio }\end{array}$ & $15.24 \%$ & $28.66 \%$ & $21.34 \%$ & $15.85 \%$ & $7.32 \%$ & $11.59 \%$ & $100 \%$ \\
\hline
\end{tabular}

Table 3 Observed frequencies: Share of development investment - WPI companies

Tablica 3. Učestalost: Udio razvojnih investicija u drvoprerađivačkim poduzećima

\begin{tabular}{|l|c|c|c|c|c|c|}
\hline $\begin{array}{l}\text { Share of development } \\
\text { investment } \\
\text { Udio razvojnih investicija }\end{array}$ & $\begin{array}{c}\text { Group 0 } \\
\text { ROE < } \\
\text { Skupina } \\
\text { točka } \\
\text { povrata }<0\end{array}$ & $\begin{array}{c}\text { Group 1 } \\
\text { ROE: 0-2 \% } \\
\text { Skupina 1., } \\
\text { tockka povrata } \\
0-2 \%\end{array}$ & $\begin{array}{c}\text { Group 2 } \\
\text { ROE: 2-4 \% } \\
\text { Skupina 2., } \\
\text { točka povrata } \\
2-4 \%\end{array}$ & $\begin{array}{c}\text { Group 3 } \\
\text { ROE: 4-7 \% } \\
\text { Skupina 3., } \\
\text { točka povrata } \\
4-7 \%\end{array}$ & $\begin{array}{c}\text { Group 4 } \\
\text { ROE: 7-10 \% } \\
\text { Skupina 4., } \\
\text { točka povrata } \\
7-10 \%\end{array}$ & $\begin{array}{c}\text { Group 5 } \\
\text { ROE>10 \% } \\
\text { Skupina 5., } \\
\text { točka povrata } \\
>10 \%\end{array}$ \\
\hline $0 \%$ & 1 & 0 & 1 & 0 & 0 & 2 \\
\hline $\begin{array}{l}\text { Share in category } \\
\text { Udio po kategoriji }\end{array}$ & $50.00 \%$ & $0.00 \%$ & $50.00 \%$ & $0.00 \%$ & $0.00 \%$ & $100 \%$ \\
\hline Share in total / Udio u ukupnosti & $2.94 \%$ & $0.00 \%$ & $2.94 \%$ & $0.00 \%$ & $0.00 \%$ & $5.88 \%$ \\
\hline up to 25\% / do 25\% & 4 & 8 & 5 & 1 & 3 & 21 \\
\hline $\begin{array}{l}\text { Share in category } \\
\text { Udio po kategoriji }\end{array}$ & $19.05 \%$ & $38.10 \%$ & $23.81 \%$ & $4.76 \%$ & $14.29 \%$ & $100 \%$ \\
\hline Share in total / Udio u ukupnosti $\%$ & $11.76 \%$ & $23.53 \%$ & $14.71 \%$ & $2.94 \%$ & $8.82 \%$ & $61.76 \%$ \\
\hline up to 50\% / do 50\% & 2 & 2 & 2 & 0 & 1 & 7 \\
\hline $\begin{array}{l}\text { Share in category } \\
\text { Udio po kategoriji }\end{array}$ & $28.57 \%$ & $28.57 \%$ & $28.57 \%$ & $0.00 \%$ & $14.29 \%$ & $100 \%$ \\
\hline Share in total / Udio u ukupnosti & $5.88 \%$ & $5.88 \%$ & $5.88 \%$ & $0.00 \%$ & $2.94 \%$ & $20.59 \%$ \\
\hline up to 75 \% / do 75\% & 0 & 1 & 0 & 2 & 0 & 3 \\
\hline $\begin{array}{l}\text { Share in category } \\
\text { Udio po kategoriji }\end{array}$ & $0.00 \%$ & $33.33 \%$ & $0.00 \%$ & $66.67 \%$ & $0.00 \%$ & $100 \%$ \\
\hline Share in total / Udio u ukupnosti $\%$ & $0.00 \%$ & $2.94 \%$ & $0.00 \%$ & $5.88 \%$ & $0.00 \%$ & $8.82 \%$ \\
\hline above 75\% / vise od 75 \% & 1 & 0 & 0 & 0 & 0 & 1 \\
\hline $\begin{array}{l}\text { Share in category } \\
\text { Udio po kategoriji }\end{array}$ & $100.00 \%$ & $0.00 \%$ & $0.00 \%$ & $0.00 \%$ & $0.00 \%$ & $100 \%$ \\
\hline Share in total / Udio u ukupnosti $\%$ & $2.94 \%$ & $0.00 \%$ & $0.00 \%$ & $0.00 \%$ & $0.00 \%$ & $2.94 \%$ \\
\hline Counts total Ukupan broj & 8 & 11 & 8 & 3 & 4 & 34 \\
\hline Share total / Ukupan udio & $23.53 \%$ & $32.35 \%$ & $23.53 \%$ & $8.82 \%$ & $11.76 \%$ & \\
\hline
\end{tabular}


Table 4 Average performance by categories: Share of development investment

Tablica 4. Prosječni poslovni rezultati prema kategorijama: Udio razvojnih investicija

\begin{tabular}{|l|c|c|c|c|c|c|}
\hline $\begin{array}{l}\text { Share of development invest- } \\
\text { ment/ Performance } \\
\begin{array}{l}\text { Udio razvojnih investicija / } \\
\text { poslovni rezultati }\end{array}\end{array}$ & $\mathbf{0 \%}$ & $\begin{array}{c}\text { up to } \mathbf{2 5} \% \\
\text { do } 25 \%\end{array}$ & $\begin{array}{c}\text { up to 50 \% } \\
\text { do } 50 \%\end{array}$ & $\begin{array}{c}\text { up to 75 \% } \\
\text { do } 75 \%\end{array}$ & $\begin{array}{c}\text { above 75 \% } \\
\text { više od 75 } \\
\%\end{array}$ & $\begin{array}{c}\text { All categories } \\
\text { Sve kategorije }\end{array}$ \\
\hline $\begin{array}{l}\text { All tested companies } \\
\text { Sva promatrana poduzeća }\end{array}$ & 2.105263 & 2.010204 & 2.217391 & 2.916667 & 1.250000 & 2.060976 \\
\hline $\begin{array}{l}\text { WPI companies } \\
\text { Drvoprerađivačka poduzeća }\end{array}$ & 1.000000 & 1.714286 & 1.571429 & 2.333333 & 0.000000 & 1.647059 \\
\hline
\end{tabular}

\subsection{Investing direction}

In the analysis of investing direction, companies could choose any number of responses and identify one or more crucial approach to invest. For this reason, we did not analyze responses through cumulative values, but the relative frequencies via separate categories identified for major investment direction. All categories of investments in all tested companies $(N=164)$ compared with WPI companies $(N=34)$ are presented in Tab. 5, and categories with the largest relative abundance are presented in Figure 2.

In the sample of all tested companies, 128 firms (78 \%) identified the category of manufacturing technology, machinery and equipment as crucial in directing of investments. The most mentioned category, however, does not mean statistically significant effect on the performance of enterprises. This result was probably affected by the participation of relatively large amounts of non-manufacturing companies with-

Table 5 Areas of investments

Tablica 5. Područja investiranja

\begin{tabular}{|l|c|c|c|c|}
\hline \multirow{2}{*}{$\begin{array}{l}\text { Areas of investments } \\
\text { Područja investiranja }\end{array}$} & \multicolumn{2}{|c|}{$\begin{array}{c}\text { All tested companies } \\
\text { Sva promatrana poduzeća }\end{array}$} & $\begin{array}{c}\text { WPI companies } \\
\text { Drvopreradivačka poduzeća }\end{array}$ \\
\cline { 2 - 5 } & $\begin{array}{c}\text { Number of } \\
\text { companies } \\
\text { Broj poduzeća }\end{array}$ & $\begin{array}{c}\text { Relative } \\
\text { Relativne } \\
\text { vrijednosti } \\
\%\end{array}$ & $\begin{array}{c}\text { Number of } \\
\text { companies } \\
\text { Broj poduzeća }\end{array}$ & $\begin{array}{c}\text { Relative } \\
\text { Relivne } \\
\text { vrijednosti } \\
\%\end{array}$ \\
\hline $\begin{array}{l}\text { Technology, machinery, equipment } \\
\text { Tehnologija, postrojenja, oprema }\end{array}$ & 128 & 78 & 33 & 97 \\
\hline Intangibles /Investicije u nematerijalno & 55 & 34 & 5 & 15 \\
\hline Construction investments / Konstrukcijske investicije & 51 & 31 & 12 & 35 \\
\hline $\begin{array}{l}\text { Training and staff development } \\
\text { Edukacija i razvoj kadrova }\end{array}$ & 46 & 28 & 9 & 26 \\
\hline Research and development / Istraživanje i razvoj & 18 & 11 & 1 & 3 \\
\hline Financial investments / Investicije u kapital & 17 & 10 & 4 & 12 \\
\hline Vehicles / Vozni park & 2 & 1 & 0 & 0 \\
\hline Quality assurance / Osiguranje kvalitete & 2 & 1 & 0 & 0 \\
\hline Marketing / Marketing & 1 & 1 & 0 & 0 \\
\hline Without investment / Bez investicija & 2 & 1 & 0 & 0 \\
\hline $\begin{array}{l}\text { 162 of 164 companies invest } \\
\text { investiraju 162 od 164 poduzeća }\end{array}$ & 162 & 99 & 34 & 100 \\
\hline Total number of answers / Ukupan broj odgovora & 164 & 100 & 34 & 100 \\
\hline
\end{tabular}

Technology, machinery, equiment tehnologija, strojni park, oprema
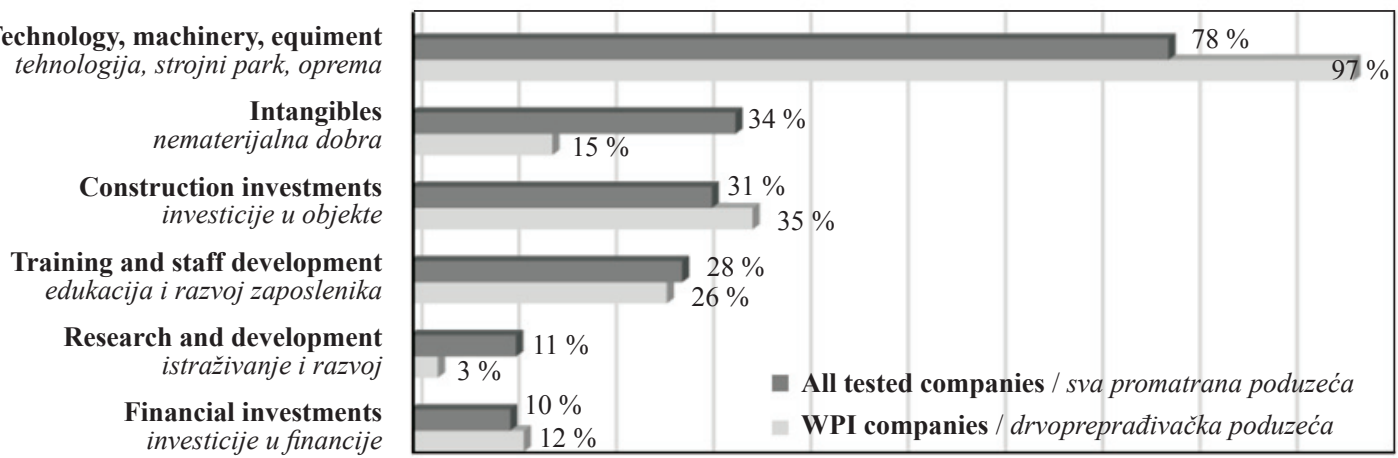

Figure 2 Investing direction - the most observed relative frequencies

Slika 2. Područje investiranja - najučestalija područja, relativne vrijednosti 
Table 6 Contingency: Industry vs. Intangible investment - statistics

Tablica 6. Vjerojatnost: Industrija i investicije u nematerijalno - statistika

\begin{tabular}{|l|c|c|c|}
\hline Statistics / Statistika & Chi-square $\chi^{2}$ & $\boldsymbol{d f}$ & $\boldsymbol{p}$ \\
\hline Pearson's chi-square / Pearsonov $\chi^{2}$ & 10.75800 & $d f=3$ & $p=0.01311$ \\
\hline M-L chi-square / M-L $\chi^{2}$ & 11.24314 & $d f=3$ & $p=0.01048$ \\
\hline Contingency coefficient(CC) / Koeficijent vjerojatnosti (CC) & 0.2481117 & & \\
\hline Cramér V coefficient / Cramerov V koeficijent & 0.2561202 & & \\
\hline Adjusted CC / Prilagođen CC & 0.32528 & & \\
\hline
\end{tabular}

Table 7 Contingency; Industry vs. Intangible investment - frequencies

Tablica 7. Vjerojatnost: Industrija i investicije u nematerijalno - učestalost

\begin{tabular}{|c|c|c|c|c|c|}
\hline $\begin{array}{l}\text { Industry / Intangible investment } \\
\text { Industrija / investicije u nematerijalno }\end{array}$ & $\begin{array}{c}\text { Wood } \\
\text { Processing } \\
\text { Prerada drva } \\
\end{array}$ & $\begin{array}{l}\text { Automotive } \\
\text { Auto industrija }\end{array}$ & $\begin{array}{l}\text { Other } \\
\text { Ostalo }\end{array}$ & $\begin{array}{c}\text { Engineering } \\
\text { Metaloprerađivačka } \\
\text { industrija } \\
\end{array}$ & $\begin{array}{c}\text { Row } \\
\text { Totals } \\
\text { Ukupno } \\
\end{array}$ \\
\hline \multicolumn{6}{|c|}{ Observed Frequencies / Dobivena učestalost } \\
\hline $\begin{array}{l}\text { Crucial investment } \\
\text { Nisu ključne investicije }\end{array}$ & 29 & 11 & 55 & 14 & 109 \\
\hline Crucial investment / Ključne investicije & 5 & 5 & 29 & 16 & 55 \\
\hline Totals / Ukupno & 34 & 16 & 84 & 30 & 164 \\
\hline \multicolumn{6}{|c|}{ Expected Frequencies / Očekivana učestalost } \\
\hline $\begin{array}{l}\text { Not crucial investment } \\
\text { Nisu ključne investicije }\end{array}$ & 22.59756 & 10.63415 & 55.82927 & 19.93902 & 109.0000 \\
\hline Crucial investment / Ključne investicije & 11.40244 & 5.36585 & 28.17073 & 10.06098 & 55.0000 \\
\hline Totals / Ukupno & 34.00000 & 16.00000 & 84.00000 & 30.00000 & 164.0000 \\
\hline \multicolumn{6}{|l|}{ Residual Frequencies / Učestalost ostatka } \\
\hline $\begin{array}{l}\text { Not crucial investment } \\
\text { Nisu ključne investicije }\end{array}$ & 6.40244 & 0.365854 & -0.829268 & -5.93902 & 0.00 \\
\hline Crucial investment / Ključne investicije & -6.40244 & -0.365854 & 0.829268 & 5.93902 & 0.00 \\
\hline Totals / Ukupno & 0.00000 & 0.000000 & 0.000000 & 0.00000 & 0.00 \\
\hline
\end{tabular}

out technology investment but with higher business performance. The second most numerous category was intangible investment. Research was not interested in the volume of investments of a certain category.

Relatively more wood processing companies (97 $\%$ share compared with the sample of all tested companies with $78 \%$ share, which also consisted of trade and service businesses without the need of technology) invest in production technology and machinery. However, a lot of companies realize only recovery, not development investment, so this category does not lead to higher performance.

We analyzed if an investing direction is more typical for some industry or specialization and whether the direction to intangible investment is statistically significant. As demonstrated in the last research (Rajnoha et al., 2013), just intangible investment (in foreign ownership companies) causes higher performance. Category of intangibles as crucial investment is mostly typical for engineering industry, and not at all for wood processing industry, as shown by statistical analysis presented in Tab. 6 and 7.

3.3 Investment project preparation
3.3. Priprema investicijskih projekata

Similarly as in the previous analysis, efforts were made to identify some differences in investment behavior, with the focus on the preparation of investment projects in specific industries.

From the statistical results (Tab. 8 and 9), it can be stated that the preparation of investment projects is characteristic for the category of engineering and automotive industries, while the WPI industry and other sectors do not consider the preparation of investment projects as principal.

In relation to the achieved performance in these sectors (see more in Rajnoha et al., 2013), which follows the relationship of industry and preparation of investment projects, this means higher performance in the engineering and automotive industries, but lower

Table 8 Contingency: Industry vs. Investment project preparation - statistics

Tablica 8. Vjerojatnost: Industrija i priprema investicijskih projekata - statistika

\begin{tabular}{|l|c|c|c|}
\hline Statistics / Statistika & Chi-square $\chi^{2}$ & $d f$ & $p$ \\
\hline Pearson's chi-square / Pearsonov $\chi^{2}$ & 7.123180 & $d f=3$ & $p=0.06807$ \\
\hline M-L chi-square / M-L $\chi^{2}$ & 8.260908 & $d f=3$ & $p=0.04092$ \\
\hline Contingency coefficient (CC) / Koeficijent vjerojatnosti (CC) & 0.2040246 & & \\
\hline Cramér V coefficient / Cramerov V koeficijent & 0.2084083 & & \\
\hline Adjusted CC / Prilagođen CC & 0.26429 & & \\
\hline
\end{tabular}


Table 9 Contingency; Industry vs. Investment project preparation - frequencies

Tablica 9.Vjerojatnost: Industrija i priprema investicijskih projekata - učestalost

\begin{tabular}{|c|c|c|c|c|c|}
\hline $\begin{array}{l}\text { Industry / Investment project preparation } \\
\text { Industrija / priprema investicijskih projekata }\end{array}$ & $\begin{array}{l}\text { Other } \\
\text { Ostalo }\end{array}$ & $\begin{array}{l}\text { Wood Processing } \\
\text { Prerada drva }\end{array}$ & $\begin{array}{l}\text { Automotive } \\
\text { Autoindustrija }\end{array}$ & $\begin{array}{l}\text { Engineering } \\
\text { Metalo- } \\
\text { prerađivačka } \\
\text { industrija }\end{array}$ & $\begin{array}{c}\text { Row } \\
\text { Totals } \\
\text { Ukupno }\end{array}$ \\
\hline \multicolumn{6}{|l|}{ Observed Frequencies / Dobivena učestalost } \\
\hline $\begin{array}{l}\text { Without investment projects } \\
\text { Bez investicijskih projekata }\end{array}$ & 24 & 8 & 2 & 2 & 36 \\
\hline $\begin{array}{l}\text { With investment projects } \\
\text { S investicijskim projektima }\end{array}$ & 60 & 26 & 14 & 28 & 128 \\
\hline Totals / Ukupno & 84 & 34 & 16 & 30 & 164 \\
\hline \multicolumn{6}{|l|}{ Expected Frequencies / Očekivna učestalost } \\
\hline $\begin{array}{l}\text { Without investment projects } \\
\text { Bez investicijskih projekata }\end{array}$ & 18.43902 & 7.46341 & 3.51220 & 6.58537 & 36.0000 \\
\hline $\begin{array}{l}\text { With investment projects } \\
\text { S investicijskim projektima }\end{array}$ & 65.56098 & 26.53659 & 12.48780 & 23.41463 & 128.0000 \\
\hline Totals / Ukupno & 84.00000 & 34.00000 & 16.00000 & 30.00000 & 164.0000 \\
\hline \multicolumn{6}{|l|}{ Residual Frequencies / Učestalost ostatka } \\
\hline $\begin{array}{l}\text { Without investment projects } \\
\text { Bez investicijskih projekata }\end{array}$ & 5.56098 & 0.536585 & -1.51220 & -4.58537 & 0.00 \\
\hline $\begin{array}{l}\text { With investment projects } \\
\text { S investicijskim projektima }\end{array}$ & -5.56098 & -0.536585 & 1.51220 & 4.58537 & 0.00 \\
\hline Totals / Ukupno & 0.00000 & 0.000000 & 0.00000 & 0.00000 & 0.00 \\
\hline
\end{tabular}

performance in WPI and other industries. It can be said that preparation of investment projects affects the performance of enterprises. Unfortunately, direct evidence about the relationship between the preparation of investment projects and achieved business performance could not be statistically proven.

\section{DISCUSSION AND CONCLUSIONS 4 DISKUSIJA I ZAKLJUČCI}

Selected areas of investment management were analyzed in Slovak companies with the focus on companies of wood processing industry. The result of complex research shows lower performance in the mentioned industry compared with the average of all tested companies or some selected industries (automotive, engineering, etc.). In the present paper, efforts were made to identify crucial problems in investment behavior and trends in wood processing companies affecting low business performance. The main results in this part of research can be summarized as follows.

First, intangible investments, which are crucial for better performance, are not a typical investment activity of WPI companies. On the other hand, engineering industry, where intangibles are crucial investment, reached better performance than wood processing industry.

Second, preparation of investment projects is characteristic for the category of engineering and automotive industries, while the WPI industry and other sectors do not consider the preparation of investment projects as principal. The same trend is observed in achieved performance in separate categories of industry: Engineering and automotive with investment projects and higher performance, in contrast with absence of investment projects and lower performance in wood processing industry.
The wood processing industry in Slovakia is currently in a difficult situation, but there are still possibilities for better investment management and potential of positive impact on performance of companies.

\section{REFERENCES}

5. LITERATURA

1. Brealey, M. A.; Myers, S. C., 2003: Principles of Corporate Finance. New York: McBraw Hill.

2. Brealey, M. A.; Myers, S. C., 1999: Financial Theory and Corporate Policy. Praha: EAST Publishing, p. 971.

3. Damodaran, A., 2012: Investment valuation, tools and techniques for determining the value of any asset, $3^{\text {rd }}$ ed. New Jersey: John Wiley \& Sons.

4. Drábek, J.; Jelačić, D., 2007: Investment Projects. Zvolen: Nikara, p. 65.

5. Drábek, J.; Merková, M., 2010: Efektívnost' priamych zahraničných investícií $\mathrm{v}$ odvetví spracovania dreva. Vydavatel'stvo TU Zvolen, p.103.

6. Drevospracujúci priemysel. Agentúra SARIO. [online]. http://www.sario.sk/?drevospracujuci-priemysel.

7. Kislingerová, E., 1999: Oceňovánípodniku. Praha: C. H. Beck, 304 p.

8. Kislingerová, E. et al., 2010: Manažerské finance, 3rd Ed. Praha: C. H. Beck, p. 826.

9. Knápkova, A.; Pavelková, D., 2010: Finančníanalýza: Komplexníprůvodce s př́klady. Praha: Grada Publishing, p. 208.

10. Merková, M.; Drábek, J.; Polách, J., 2011: Impact of Investment on Labour Productivity Growth in Wood Processing Industry in Slovak Republic. Finance and the Performance of Firms in Science, Education and Practice. International Scientific Conference, 324-332.

11. Merková, M.; Drábek, J., 2011: Potential of Effects from Foreign Direct Investment. Development trends in economics and management in wood processing and furniture manufacturing. International Scientific Conference, 115-124. 
12. Merková, M.; Drábek, J., 2013: Vybrané metódy merania a riadenia výkonnosti podnikov $\mathrm{v}$ investičnejoblasti. Ekonomika a manažmentpodnikov 2013, International Scientific Conference, 259-264.

13. Merková, M.; Drábek, J.; Jelačić, D., 2012: Determinants of Effects of Foreign Direct Investment in Terms of Slovak Republic and Wood-Processing Industry of Slovakia. Drvna industrija, 63(2): 129-142. http://dx.doi.org/10.5552/drind.2012.1136

14. Moravčík, M., 2007: Vypracovanie lesníckej časti prognózy a vízie vývoja slovenského pol'nohospodárstva, potravinárstva, lesníctva a vidiek asprávy zaúlohy riešené v roku 2007 v rámcikontraktu, ktorý bol uzavretý medzi MP SR a NLC. http://www.nlcsk.sk/files/1231.pdf

15. Ojurović, R.; Moro, M.; Šegotić, K.; Grladinović, T.; Oblak, L., 2013: Analysis of the investment in wood processing and furniture manufacturing entities by key factors of competitiveness. Drvna industrija, 64(2): 131-137. http://dx.doi.org/10.5552/drind.2013.1235

16. Pearson, K., 1904: On the Theory of Contingency and its Relation to Association and Normal Correlation. London: Dulau\& Company.

17. Polách, J.; Drábek, J.; Merková, M.; Polách, J. Jr., 2012: Real and Financial Investment. $1^{\text {st }}$ ed. Praha: C. H. Beck. $264 \mathrm{p}$.

18. Questionnaire Surveyof the Grant Project of the Ministry of Education Nr. 1/0089/11 - Measurement and performance management of the wood industry companies in SR.

19. Rajnoha, R. et al., 2013: Meranie a riadenievýkonnostipodnikov. Zvolen: Vydavatel'stvo TU Zvolen, 313 p.

20. Rajnoha, R.; Jankovský, M.; Merková, M., 2014: Economic comparison of automobiles with electric and with combustion engines: An analytical study. Procedia - social and behavioral sciences, 109: 225-230. http://dx.doi.org/10.1016/j.sbspro.2013.12.449

21. Rimarčík, M., 2007: Statistics pre prax. Košice: Enigma, $200 \mathrm{p}$.

22. Sujová, A.; Rajnoha, R.; Merková, M., 2014: Business process performance management principles used in Slovak enterprises. Procedia - social and behavioral sciences 109: 276-280.

http://dx.doi.org/10.1016/j.sbspro.2013.12.457

\section{Corresponding address:}

Prof. DENIS JELAČIĆ, Ph.D.

University of Zagreb

Faculty of Forestry

Svetošimunska 25

HR-10000 Zagreb, CROATIA

e-mail: djelacic@sumfak.hr

\section{Ispravak / errata corrige}

U radu „Some Physical and Mechanical Properties of Borate-Treated Oriental Beech Wood“ autora Hakana Simseka i Erguna Baysala, objavljenome u broju 2 /2015 časopisa Drvna industrija, pogreškom je ostala nepromjenjena mjerna jedinica u 4 . koloni tablice 3 , koja umjesto g/ $\mathrm{cm}^{3}$ treba biti N/mm².

Uredništvo se ispričava autorima zbog nenamjerne pogreške u pripremi rada za objavljivanje.

\section{Correction / errata corrige}

In the paper „Some Physical and Mechanical Properties of Borate-Treated Oriental Beech Wood“ by Hakan Simsek i Ergun Baysal published in Drvna industrija No.2 /2015, the measurement unit in table 3, column 4 should be $\mathrm{N} / \mathrm{mm}^{2}$ instead $\mathrm{g} / \mathrm{cm}^{3}$.

The Editorial Board would like to apologize to the authors for unintended errors occurred during the preparation of the paper for publishing. 